\title{
REKAMAN BARU FISSIDENS (BRYOPHYTA: FISSIDENTACEAE) UNTUK BORNEO
}

\author{
Sarah Agustiorini ${ }^{1} \&$ Nunik Sri Ariyanti ${ }^{2}$ \\ ${ }^{1}$ Program pascasarjana, Program Studi Biologi Tumbuhan, Institut Pertanian Bogor. Kampus Darmaga, Bo- \\ gor. Email: sarahagustio@gmail.com \\ ${ }^{2}$ Departemen Biologi, Fakultas Matematika dan Ilmu Pengetahuan Alam, Institut Pertanian Bogor, Kampus \\ Darmaga, Bogor. \\ Korespondensi: nuniksa@gmail.com
}

Sarah Agustiorini \& Nunik Sri Ariyanti. 2018. New records of Fissidens (Bryophyta: Fissidentaceae) for Borneo. Floribunda 6(1): 12-18. - Two species of the genus Fissidens, namely F. bogoriensis Fleisch. and F. braunii (C. Mull.) Dozy \& Molk., are reported as new records for the bryoflora of Borneo. F. bogoriensis was previously reported only occured in Java, Malay Peninsula, New Guinea, Indo-Pacific Islands, China, and Japan. F. braunii was found in Sumatra, Malay Peninsula, New Guinea and Polynesia. In the current exploration these two species were found in the Eastern Borneo. Descriptions, notes, and ilustrations are provided.

Keywords: Borneo, Fissidens, New Record.

Sarah Agustiorini \& Nunik Sri Ariyanti. 2018. Rekaman Baru Fissidens (Bryophyta: Fissidentaceae) untuk Borneo. Floribunda 6(1): 12-18. - Dua jenis dari marga Fissidens, yaitu F. bogoriensis Fleisch. dan $F$. braunii (C. Mull.) Dozy \& Molk., dilaporkan sebagai rekaman baru untuk flora lumut di Borneo. F. bogoriensis sebelumnya dilaporkan hanya terdapat di Jawa, Semenanjung Malaya, Papua Nugini, Kepulauan Indo-Pasifik, China, dan Jepang. F. braunii dilaporkan terdapat di Sumatra, Semenanjung Malaysia, Papua Nugini dan Polynesia. Akan tetapi, dalam eksplorasi kali ini dua jenis tersebut ditemukan di Kalimantan Bagian Timur. Deskripsi, catatan, dan ilustrasi jenis disediakan.

Kata kunci: Borneo, Fissidens, Rekaman Baru.

Fissidens merupakan marga tunggal lumut sejati (Bryophyta) dari suku Fissidentaceae. Marga ini mudah dikenali berdasarkan perawakannya yang khas dengan daun-daun tersusun dalam dua baris pada batang. Marga Fissidens memiliki struktur daun yang kompleks, yaitu setiap lembaran daunnya terdapat pelepah pada pangkal lembaran daun bagian apikal (Pursell \& Bruggeman-Nannenga 2004). Beberapa jenis dari marga ini dimanfaatkan sebagai tumbuhan akuarium (aquascape), karena mampu hidup di dalam air dan memiliki bentuk yang unik seperti bulu burung (Beveer 2014).

Marga Fissidens yang ditemukan di Kawasan Malesia sebanyak 28 jenis (Eddy 1988), 10 jenis diantaranya terdapat di Borneo. Dari daftar jenis lumut sejati untuk wilayah Borneo (termasuk di dalamnya wilayah Indonesia, Malaysia, dan Brunei Darussalam), terdapat 37 jenis Fissidens (Suleiman et al. 2006). Namun, sebagian besar Fissidens di Borneo yang dilaporkan berasal dari wilayah Malaysia (Sabah dan Serawak), dan jenisjenis Fissidens yang dilaporkan ada di wilayah Indonesia hanya 9 jenis (18\%) (Suleiman et al.
2006). Berdasarkan spesimen Fissidens yang dikumpulkan dari Kalimantan Bagian Timur, ditemukan dua jenis rekaman baru pada bryoflora Pulau Borneo, yaitu F. bogoriensis dan F. braunii.

\section{BAHAN DAN METODE}

Spesimen lumut Fissidens yang diamati berasal dari Kalimantan Bagian Timur (Provinsi Kalimantan Timur dan Provinsi Kalimantan Utara, Indonesia), terdiri atas 498 specimen yang dikoleksi pada penelitian ini dan 52 spesimen yang sebelumnya telah dikoleksi dan disimpan di Herbarium Bogoriense. Kegiatan eksplorasi pengambilan sampel dilakukan dengan menggunakan metode jelajah dengan mengikuti Rugayah dkk. (2004), untuk mengoleksi spesimen dilakukan di 11 lokasi pada bulan Februari hingga Mei 2016. Lokasi eksplorasi mencakup daerah dataran, lereng perbukitan hingga puncak bukit, sepanjang sungai dan air terjun yang menjadi habitat lumut (10-450 $\mathrm{m}$ dpl). Setiap spesimen yang dikoleksi dari lapangan diberi nomor koleksi, waktu dan lokasi pengambilan, selanjutnya dibuat spesimen her- 
barium mengikuti cara pengoleksian dan pengawetan Gradstein et al. (2001). Spesimen herbarium yang sudah diidentifikasi disimpan di Herbarium Bogoriense (BO), spesimen duplikat disimpan di Herbarium BIOTROP (BIOT) dan Laboratorium Ekologi Sumberdaya dan Taksonomi Tumbuhan, Departemen Biologi Fakultas MIPA, IPB. Pengamatan morfologi pada spesimen dilakukan dengan menggunakan mikroskop stereo. Pengamatan anatomi dilakukan dengan membuat sayatan transversal daun dan batang menggunakan pisau silet dibawah mikroskop stereo. Sediaan spesimen diamati menggunakan mikroskop majemuk Olympus CX 23 dengan perbesaran mulai dari 4x10 hingga 10x40. Pembuatan foto morfologi dan anatomi menggunakan OptiLab Viewer 2.2. Identifikasi jenis menggunakan pustaka seperti Mosses of the Philippines (Bartram 1939), a Handbook of Malesian Mosses, Vol. 1 (Eddy 1988), Flora of New Zealand: Mosses Fissidenstaceae (Beever 2014), Flora Neotropica Vol. 101: Fissidentaceae (Pursell 2007). Penggunaan istilah-istilah botani dalam deskripsi mengacu pada Rifai \& Puryadi (2008).

Istilah khusus digunakan untuk mendeskripsikan variasi bagian-bagian daun (Gambar 1) yaitu:

- Daun bagian distal (setengah bagian daun dari pangkal ke ujung yang berada lebih jauh dari batang, merupakan setengah bagian lebih jauh dari ujung batang, tanpa lembaran pelepah; dapat disebut juga bagian dorsal/abaksial).

- Daun bagian apikal (setengah bagian daun dari pangkal hingga ujung yang berada lebih dekat dengan ujung batang, di bagian pangkal terdapat lembaran pelepah; dapat disebut juga bagian ventral/adaksial).

- Lembaran pelepah atau vaginan lamina (bagian daun yang memiliki dua lapisan lembaran daun, terdapat pada pangkal daun bagian apikal).

- Sempadan atau limbidium (tepi lembaran daun dengan satu atau beberapa baris sel-sel berbeda bentuk atau ketebalan dindingnya dari sel-sel di bagian tengah lembaran daun), tulang daun atau kosta (bagian di tengah daun yang tersusun atas beberapa lapis sel, memisahkan daun bagian distal dan apikal).

- Istilah khusus untuk menjelaskan variasi ciri tulang daun yaitu:

- Decurrent (pangkal daun yang dari titik perlekatannya pada batang melanjut ke bawah sehingga memanjang dan menyempit).

- Excurrent (tulang daun yang memanjang hingga melebihi ujung daun).

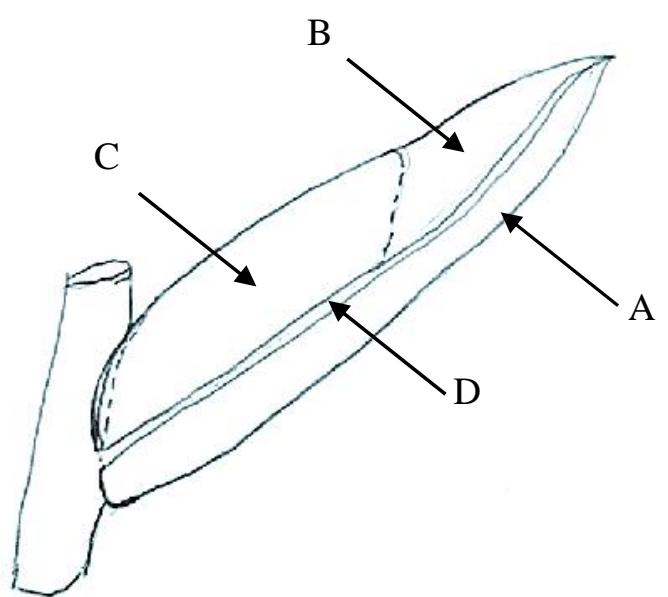

Gambar 1. Bagian-bagian daun Fissidens: A. daun bagian distal, B. daun bagian apikal, C. lembaran pelepah, D. tulang daun.

Istilah khusus untuk mendeskripsikan variasi anatomi tulang daun yang diamati pada sayatan melintang daun dan melewati bagian lembaran pelepah daun mengikuti Bruggeman-Nannenga (1990) sebagai berikut:

- Tipe bryoides yaitu tulang daun yang memiliki dua sel pendamping (guide cells) pada tepi apical tulang daun (tepi yang berhubungan dengan lembaran pelepah), dan satu atau lebih sel pusat berukuran besar (jika satu maka terletak di antara sel pendamping, jika lebih dari satu maka satu terletak di antara sel pendamping dan sel lainnya terletak di bagian dorsal tulang daun), serta di bagian lateral (tepi kanan dan kiri tulang daun) masing-masing terdapat satu berkas sel kecil dengan ruang sel agak besar berdinding tipis, atau satu berkas sel stereid (sel kecil, ruang sel sempit, dinding sel tebal).

- Tipe oblongifolius yaitu tulang daun yang memiliki 4-7(-16) sel pendamping berderet membentuk $\mathrm{V}$ atau $\mathrm{U}$, dan 1-5 sel pusat berukuran besar yang tersusun dalam 2(-3) baris, serta 3 berkas sel stereid ( 2 di bagian lateral, 1 di bagian apikal).

- Tipe taxifolius yaitu tulang daun yang memiliki (2-)4-12 sel pendamping berderet pada tepi apikal tulang daun, 1-8 sel pusat berukuran besar yang tersusun dalam 1(-2) baris atau tidak beraturan, dan dua berkas sel stereid di bagian lateral, serta sel epidermis yang memiliki ruang sel relatif besar.

- Istilah unting pusat (central strand) digunakan untuk bagian anatomi batang yang diamati pada 
irisan melintang, berupa sekumpulan sel-sel pada bagian pusat yang tampak berukuran lebih kecil dari sel-sel di bagian sekelilingnya. Bagian unting pusat pada irisan membujur batang merupakan sekumpulan sel-sel memanjang seperti sel pembuluh.

Beberapa istilah lain untuk mendeskripsikan variasi ciri Fissidens adalah :

- Kapsul (bagian dari sporofit, merupakan sporangium atau kotak spora, tempat dihasilkannya spora lumut)

- Seta atau tangkai (bagian sporofit seperti tangkai yang mendukung kapsul)

- Perikatium (daun generatif atau daun yang melindungi struktur reproduksi),

- Hyaline (bening, hialin adalah sel yang bening).

\section{HASIL DAN PEMBAHASAN}

Dari hasil pengamatan dan identifikasi spesimen didapatkan 21 jenis; dua di antaranya merupakan rekaman baru untuk Borneo, yaitu $F$. bogoriensis Fleisch., dan F. braunii (C. Mull.) Dozy \& Molk. F. bogoriensis sebelumnya diketahui tersebar di Jawa, Semenanjung Malaya, New Guinea dan Pulau-pulau besar Indo-Pasifik, Laos serta Cina dan Jepang (Eddy 1988; Suzuki \& Iwatsuki 2013; Suzuki 2016). Sementara F. braunii sebelumnya dilaporkan hanya terdapat di Sumatra, Semenanjung Malaya, New Guinea, dan Polinesia (Bartram 1939; Eddy 1988; Windadri 2010). Dua jenis rekaman baru untuk Borneo tersebut dapat dikenali dari jenis-jenis lain di Borneo berdasarkan kunci identifikasi berikut.

\section{Kunci Identifikasi Jenis Fissidens di Borneo}

\begin{tabular}{|c|c|c|}
\hline & $\mathrm{a}$ & 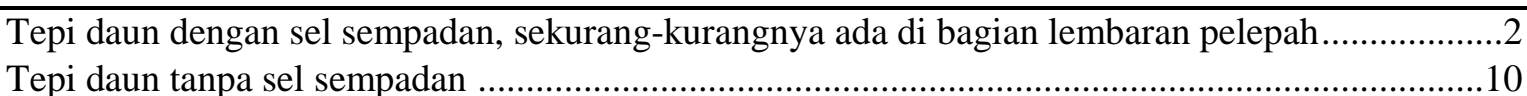 \\
\hline 2 & $\mathrm{a}$ & tidak hyalin \\
\hline & $\mathrm{b}$ & Sel-sel sempadan memanjang, ramping, ujungnya meruncing, hyaline \\
\hline 3 & $\mathrm{a}$ & $\begin{array}{l}\text { Perawakan berukuran sedang, tinggi } 4-16 \mathrm{~mm} \text {, daun } 20-42 \text { pasang, permukaan lembar daun ber- } \\
\text { gelombang }\end{array}$ \\
\hline & b & Perawakan berukuran besar, tinggi $30-90 \mathrm{~mm}$, daun 60-120 pasang, permukaan lembar da \\
\hline
\end{tabular}

4 a Ujung tulang daun berakhir sebelum ujung daun atau tidak sampai pada ujung daun

b Ujung tulang daun berakhir pada ujung daun atau melebihi ujung daun

5 a Sel sempadan hanya terdapat pada tepi bagian lembaran pelepah.................................................6

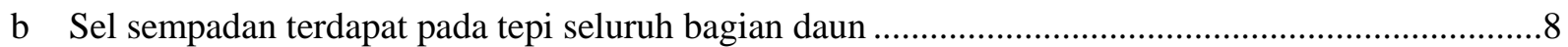

6 a Anatomi sayatan melintang batang tersusun atas selapis sel epidermis berdinding tipis berdiameter 5-10 $\mu \mathrm{m}$ dan 1 lapis sel subepidermis berdinding tipis berdiameter $14-40 \mu \mathrm{m}$. bentuk daun melanset, rasio panjang terhadap lebar $6: 1$, ujung daun meruncing sempit $\left(<45^{\circ}\right) \ldots \ldots \ldots \ldots \ldots \ldots . . . . F$. wichurae

b Anatomi sayatan melintang batang tersusun atas 1-2 lapis sel epidermis berdinding tebal berdiameter 3-4 $\mu \mathrm{m}$ dan 2-3 lapis sel subepidermis berdinding tebal berdiameter 5-14 $\mu \mathrm{m}$, bentuk daun melanset-ovate rasio panjang terhadap lebar $3-4: 1$, ujung daun meruncing $\left(45^{\circ}\right)$.............................

7 a Terestrial, panjang daun $0.5-1 \mathrm{~mm}$, lebar daun $0.2-0.3 \mathrm{~mm}$, sel sempadan pada daun vegetatif dan

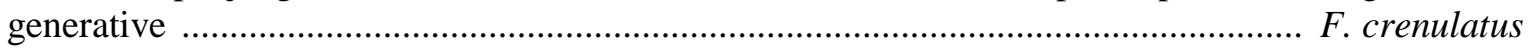

b Semi akuatik, panjang daun 1.5-2 mm, lebar daun 0.3-0.5 mm, sel sempadan hanya pada daun generatif (perikatium) .......................................................................................... . hollianus

8 a Tulang daun tipe bryoides, bentuk daun lonjong-melonjong, ujung daun meruncing $\left(45^{\circ}\right)$............9

b Tulang daun tipe oblongifolius, bentuk daun lanset atau lanset memanjang, ujung daun runcing

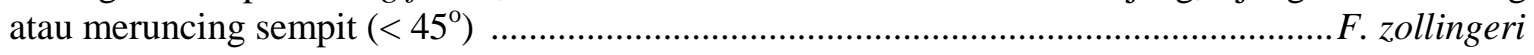

9 a Pangkal daun bagian apikal rata, ujung daun meruncing sempit $\left(<45^{\circ}\right)$, diameter sel lembar daun 20-44 $\mu \mathrm{m}$......................................................................................................... F. bogoriensis

b Pangkal daun bagian apikal menyempit membundar, ujung daun meruncing (acute), diameter sel lembar daun 5-8 $\mu \mathrm{m}$................................................................................................ F. bryoides

10 a Ujung daun meruncing sempit $\left(<45^{\circ}\right)$, sel lembar daun berdiameter 10-29 m ..........................11

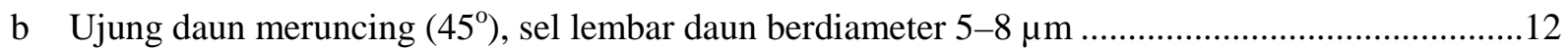




\section{Kunci Identifikasi Jenis Fissidens di Borneo (lanjutan)}

11 a Jumlah daun 11-14 pasang, permukaan daun rata, diameter sel lembar daun 10-15 $\mu \mathrm{m}$, sporofit 1 pada daun perikatium ........................................................................................ F. crassinervis

b Jumlah daun 6-9 pasang, permukaan daun bergelombang, diameter sel lembar daun 19-29 $\mu \mathrm{m}$, sporofit 2 pada daun perikatium ................................................................................... F. serratus

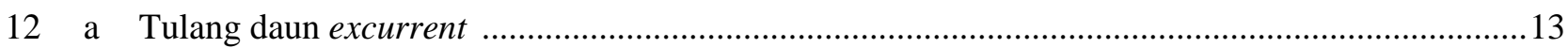

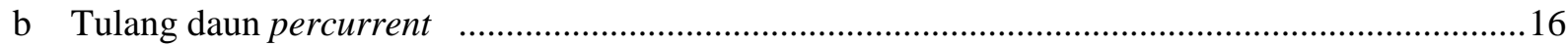

13 a Anatomi sayatan melintang batang tersusun atas 1-2 lapis sel epidermis berdinding tebal berdiameter 2-4 $\mu \mathrm{m}$ dan 2-3 lapis sel subepidermis berdinding tebal berdiameter 5-10 $\mu \mathrm{m}$, jumlah pasang daun dalam satu batang 15-46 pasang, tipe tulang daun taxifolius

b Anatomi sayatan melintang batang tersusun atas 1-2 lapis sel epidermis berdinding tipis hingga tebal berdiameter $4-5 \mu \mathrm{m}$ dan 2 lapis sel subepidermis berdinding tipis berdiameter $8-20 \mu \mathrm{m}$, jumlah pasang daun dalam satu batang 10-14 pasang, tipe tulang daun oblongifolius

14 a Diameter sel lembar daun 12-15 $\mu \mathrm{m}$, sporofit 2 pada daun perikatium, tidak bercabang, akuatik .... F. areolatus

b Diameter sel lembar daun 5-8 $\mu \mathrm{m}$, sporofit 1 pada daun perikatium, bercabang, teresterial F. braunii

15 a Sel pada lembaran daun tidak berpapil, sel tepi daun mengkilap hampir transparan, tepi daun beringgit kecil F. geminiflorus

b Sel pada lembaran daun berpapil, sel tepi daun hijau gelap, tepi daun beringgit F. robinsonii

16 a Bentuk daun oblong, tepi daun bergerigi kecil F. longevaginatus

b Bentuk daun lanset, tepi daun bergerigi atau beringgit. 17

17 a Batang bercabang... 18

b Bantang tidak bercabang.

18 a Tipe tulang daun bryoides, tepi daun beringgit, akuatik. F. zippelianus

b Tipe tulang daun taxifolius, tepi daun bergerigi, teresterial F. perpusillus

19 a Rasio panjang terhadap lebar daun 3-4:1, tumbuhan hijau cerah, tinggi tumbuhan hingga $9.5 \mathrm{~mm}$ .F. autoicus

b Rasio panjang terhadap lebar daun 6-9:1, hijau-hijau gelap, tinggi tumbuhan hingga $17 \mathrm{~mm}$.......20

20 a Sel pada lembaran daun berpapil, tepi daun bergerigi, pangkal daun bagian distal rata, pangkal daun bagian apikal menyempit, diameter sel lembar daun 6-12 $\mu \mathrm{m}$, teresterial Fissidens sp.

b Sel pada lembaran daun tidak berpapil, tepi daun beringgit, pangkal daun bagian distal membundar, pangkal daun bagian apikal rompang atau rata, diameter sel lembar daun hingga 13-20 $\mu \mathrm{m}$, akuatik F. nigroviridis

Fissidens bogoriensis Fleisch. (Gambar 2)

F. bogoriensis Fleisch., Musci FI. Buitenzorg 1: 22 (1904); Eddy, A Handbook of Malesian Mosses 1: 57-92 (1988); Suzuki \& Iwatsuki, Hattoria 4: 47-70 (2013). Suzuki, Hattoria 7: 9-223 (2016).

Tumbuhan hijau-hijau kekuningan, kecil hingga sedang, panjang 2.5-5, lebar 1.2-2 mm. Rizoid merah kecokelatan. Batang tidak bercabang. Irisan melintang batang tersusun oleh satu lapis sel epidermis berdinding tipis berdiameter
4-5 $\mathrm{m}$ dan 2-3 lapis sel subepidermis besar berdiameter 8-20 $\mathrm{m}$, berdinding tipis dan tidak berpigmen, tanpa unting pusat. Daun bersebelah dua atau berseling, rapat, 3-9 pasang, melonjong 4:2-8:1, panjang $1-2 \mathrm{~mm}$, lebar $0.5-0.9 \mathrm{~mm}$; ujung daun runcing $45^{\circ}$, pangkal distal membulat, pangkal apikal rata; tepi daun rata sedikit bergelombang; sel sempadan 2-3 baris; tulang daun tipe bryoides, excurrent; lembar pelepah $1 / 2$ panjang daun; sel lembar daun segienam-segiempat memanjang, diameter 20-44 m, berdinding tipis; sel 
lembar pelepah 80-81 m. Sporofit satu per perikatium; seta halus, kecokelatan, panjang 4.3-4.5 $\mathrm{mm}$; kapsul horizontal, hampir simetris, panjang 0.3-0.6 mm; spora berdiameter 8-13 m.

Persebaran: Jawa, Semenanjung Malaya, Papua Nugini dan pulau-pulau Indo-Pasifik serta Laos, Cina dan Jepang (Eddy 1988; Suzuki \& Iwatzuki 2013; Suzuki 2016).

Spesimen yang diamati: Kalimantan Timur, Kota Balikpapan, Hutan Lindung Sungai Wain (SAR 2016 22, 23, 24, 25, 113, 114, 115, 137, 138, 139, 140, 141, 142); Kabupaten Mahakam Ulu, Desa Matalibaq (SAR 2016 419, 420, 421, 422); Kota Samarinda, Kebun Raya Unmul Samarinda (SAR 2016 164, 165, 166, 167, 168); Kabupaten Kutai Timur, Kecamatan Sangkima, Taman Nasional Kutai (SAR 2016 275, 276, 277, 278); BO; BOIT.
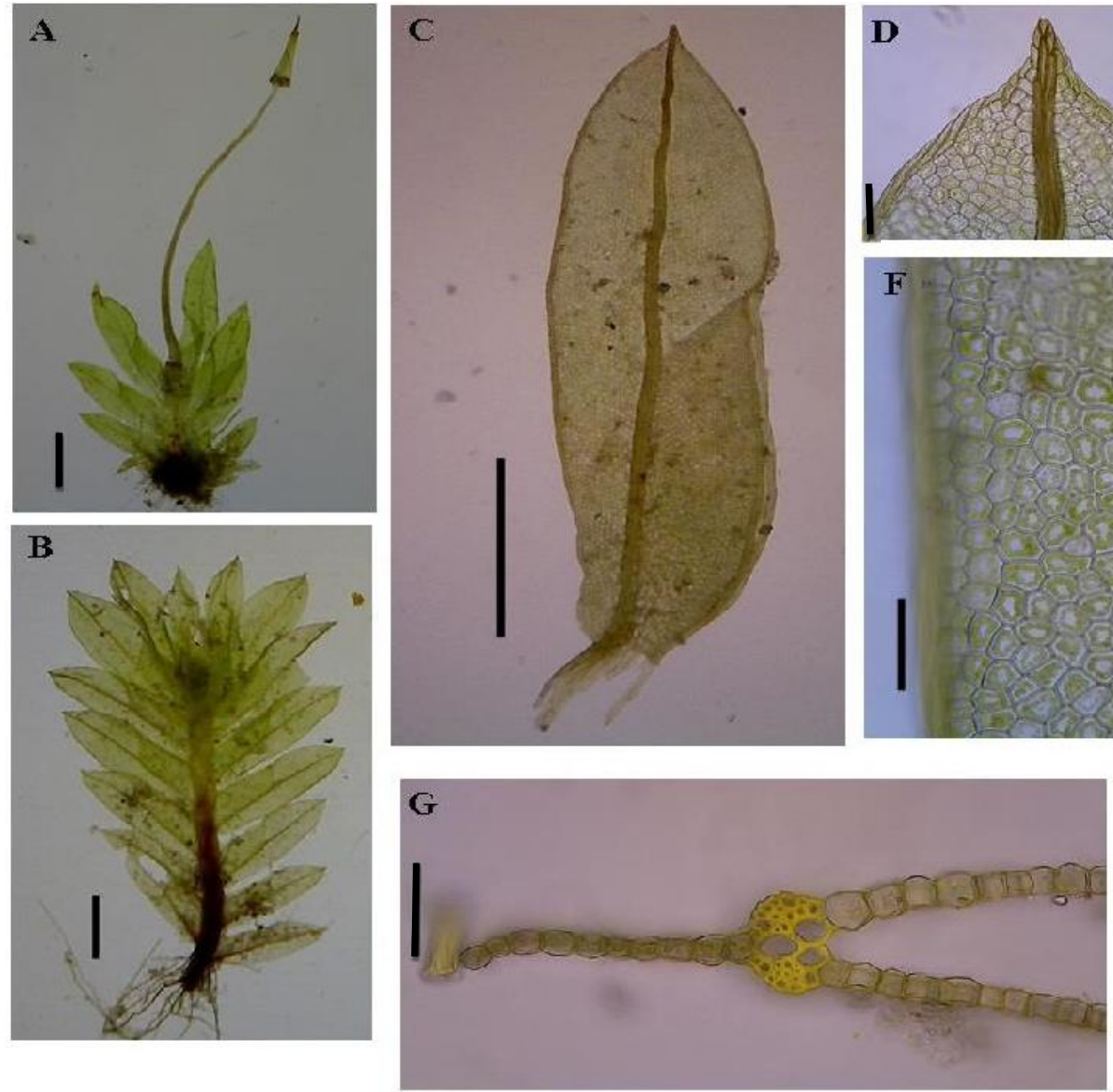

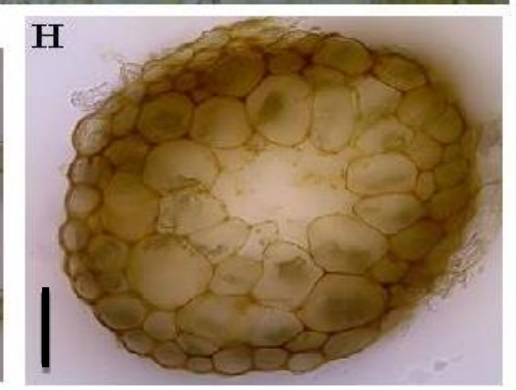

Ekologi: Jenis ini ditemukan pada ketinggian 46 hingga $152 \mathrm{~m}$ dpl. Tumbuh di habitat lantai hutan dengan kanopi tertutup atau agak terbuka dengan kondisi pepohonan yang rapat hingga jarang. Tumbuh epifit pada kulit kayu atau terestrial pada substrat tanah di dalam atau tepi hutan Dipterocarpaceae.

Catatan: Jenis ini mudah dikenali dengan melihat sel daun berbentuk heksagonal hingga membundar, berdinding tipis dan hampir transparan; sel sempadan hialin sampai ujung tulang daun. Dalam catatan Eddy (1988) jenis ini hanya memiliki tinggi $4 \mathrm{~mm}, 2-6$ pasang daun, ukuran panjang daun $1.7 \mathrm{~mm}$, lebar $0.7 \mathrm{~mm}$. Namun di Kalimantan Timur, jenis ini ditemukan lebih bervariasi dengan tinggi $2.3-7 \mathrm{~mm}$, jumlah pasang daun 3-9, panjang daun 1-2 $\mathrm{mm}$, lebar daun $0.5-0.7 \mathrm{~mm}$.
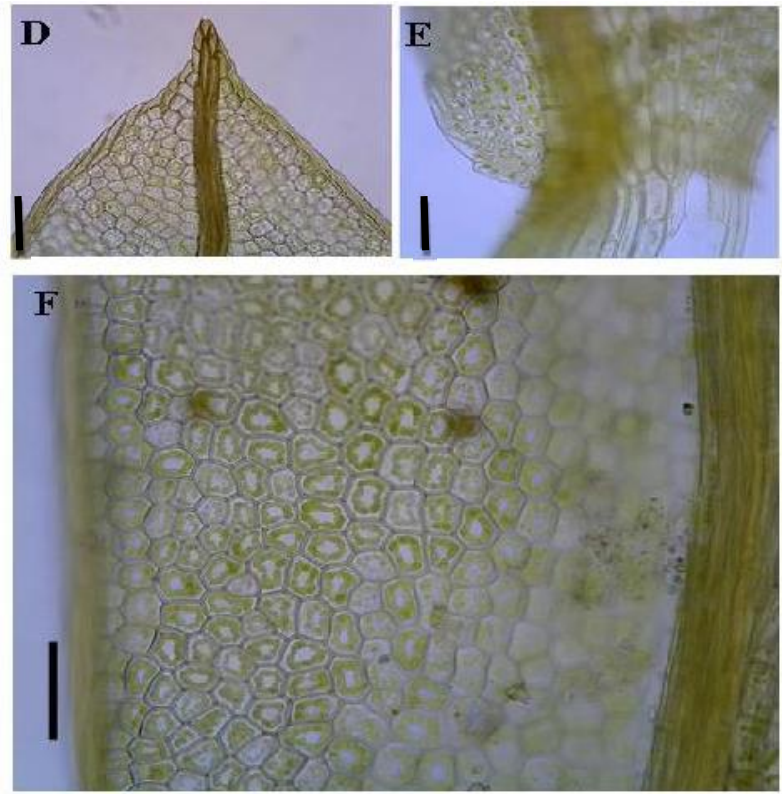

Gambar 2. F. bogoriensis: A-B. Perawakan; C. Daun; D. Ujung daun; E. Basal daun; F. Sel helai daun; G. Sayatan melintang daun dengan lembaran pelepah; H. Sayatan melintang batang (Garis skala: A-B.1 mm; C. $0.5 \mathrm{~mm}$; D-H. $50 \mu \mathrm{m})$.

Fissidens braunii (C. Mull) Dozy \& Molk. (Gambar 3)

Fissidens braunii (C. Mull) Dozy \& Molk., Bryol. Javanica 1: 1 (1854); Bartram EB, Phi. J. 
rapat. Rizoid tersebar di pangkal batang maupun ketiak daun, kuning kecokelatan-cokelat kemerahan. Batang bercabang, 1-2 di ketiak dan terminal. Irisan melintang batang tersusun oleh 1-2 lapis sel epidermis berdinding tebal berdiameter 3-4 m dan 2-4 lapis sel subepidermis berdinding tebal, berdiameter 6-16 m, berwarna hijau keputihan, tanpa unting pusat. Daun berderet dua atau berseling, rapat-jarang, 6-13 pasang, melanset 4:1, panjang 1.3-2, lebar 0.3-0.4 $\mathrm{mm}$; ujung daun runcing $45^{\circ}$, pangkal distal menguping kecil, pangkal apikal rata; tepi daun beringgit kecil; tulang daun tipe bryoides, percurrent; lembaran pelepah $1 / 2-3 / 4$ panjang daun; sel helai daun bulat-segiempat tidak beraturan, berpapil berdinding tipis, kecil, diameter 5-8 $\mathrm{m}$; daun perikatium lebih panjang hingga $2.3 \mathrm{~mm}$.

Persebaran: Jawa, Sumatra, Semenanjung Malaya, Papua Nugini (Eddy 1988; Bartram 1939; Windadri 2010).

Spesimen yang diamati: Kalimantan Timur, Kabupaten Berau, Kecamatan Biduk-biduk (SAR 2016 430, 431, 438, 439, 440, 457, 458); BO; BIOT.

Ekologi: Jenis ini ditemukan pada ketinggian 10 hingga $80 \mathrm{~m}$ dpl. Tumbuh di habitat lantai hutan dengan kanopi tertutup hingga agak terbuka dengan kondisi pepohonan yang tidak rapat. Tumbuh pada substrat batu kapur dan tanah hitam berpasir di dalam atau tepi hutan Dipterocarpaceae.
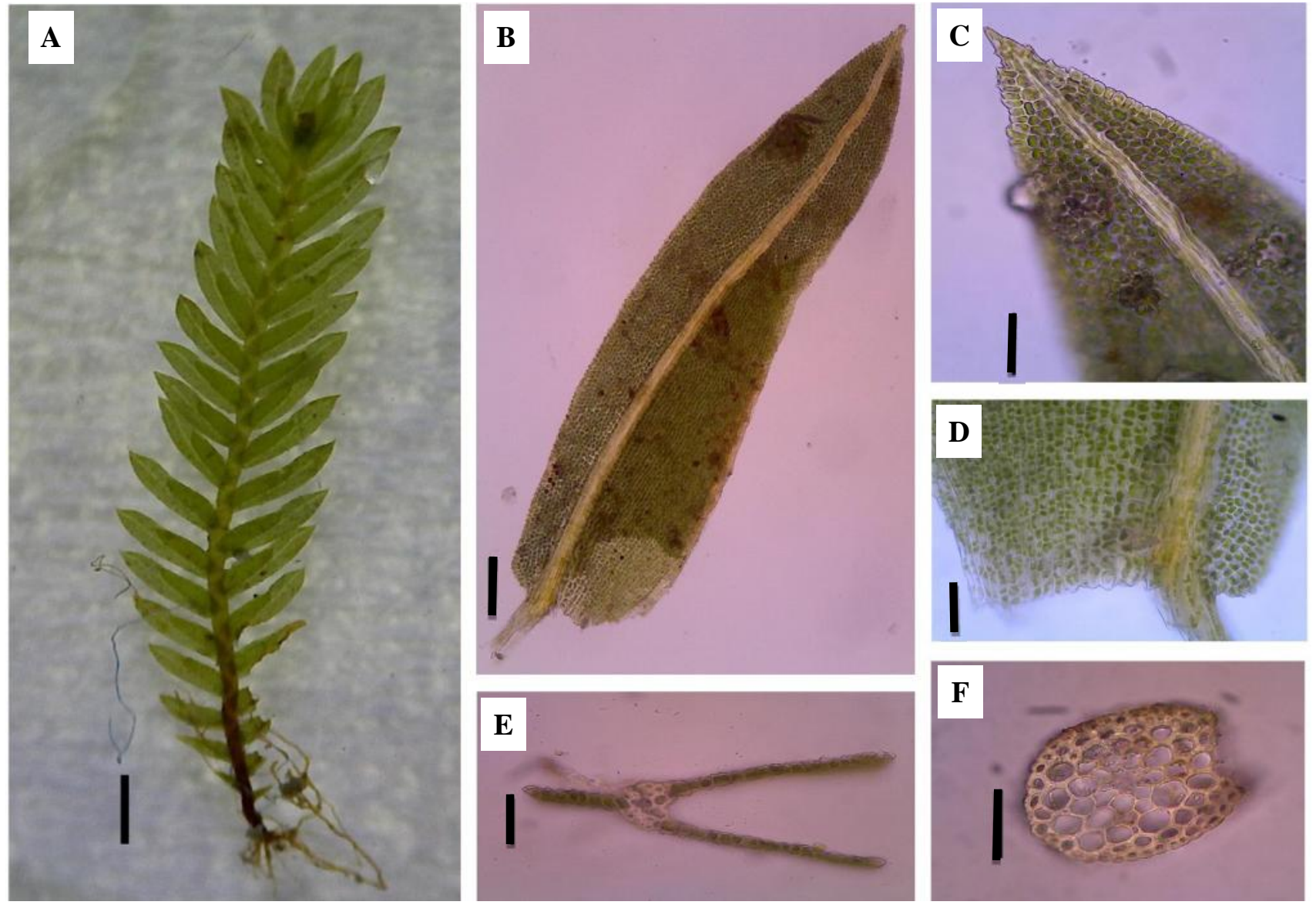

Gambar 3. F. braunii: A. Tumbuhan; B. Daun; C. Ujung daun; D. Dasar daun; E. Sayatan melintang daun lembaran pelepah; F. Sayatan melintang batang. (Garis skala: A. $1 \mathrm{~mm}$, B. $0.1 \mathrm{~mm}$, C-F. $50 \mu \mathrm{m}$ ).

\section{KESIMPULAN}

Setelah 30 tahun terbitnya $A$ Handbook of Malesian Mosses Volume 1, informasi mengenai persebaran keanekaragaman jenis tumbuhan Fissidens di kawasan Borneo bertambah. Saat ini tumbuhan Fissidens yang ditemukan di kawasan tersebut 21 jenis. Dua jenis di antaranya merupa- kan rekaman baru. Hal tersebut menunjukan bahwa diperlukan kajian khusus mengenai Flora Borneo.

\section{UCAPAN TERIMAKASIH}

Ucapan terima kasih disampaikan kepada Prof. Dr. Mien A. Rifai untuk saran dan bimbingan selama melaksanakan penelitian serta semangat 
dan perhatiannya selama menyelesaikan studi penulis pertama. Terima kasih penulis juga sampaikan kepada Herbarium Bogoriense (BO) yang telah memberikan kesempatan kepada penulis untuk memeriksa spesimen lumut. Terima kasih juga disampaikan kepada badan pengelola Hutan Lindung Sungai Wain, Badan Pengelola Taman Nasional Kutai, Laboratorium Kehati dan Ekologi Satwa Liar Fahutan Universitas Mulawarman, serta teman -teman yang telah membantu dan memberikan semangat kepada penulis pertama.

\section{DAFTAR PUSTAKA}

Bartram EB. 1939. Mosses of The Philippines. The Philippines Journal of science 68: 13-24.

Beever JE. 2014. Flora of New Zealand: mosses. Fissidentaceae. Lincoln (NZ). Manaaki Whe -nua Press.

Bruggeman-Nannenga MA. 1990. On the anatomy of the costa in Fissidens. Tropical Bryology 3: $37-44$.

Eddy A. 1988. A Handbook of Malesian Mosses Volume 1. London (GB); Natural History Museum Publications. 57-92.

Gradstein SR, Churchcill P \& Salazar AN. 2001. Guide to the Bryophytes of Tropical America. New York (US). Memoirs of the New
York Botanical Garden.

Pursell RA \& Bruggeman-Nannenga MA. 2004: A revision of the infrageneric taxa of Fissidens. Bryologist 107: 1-20.

Pursell RA. 2007: Fissidentaceae. Flora Neotropica Monograph. 101: 1-278.

Rifai MA \& Puryadi D. 2008. Glosarium Biologi. Jakarta (ID). Pusat Bahasa Departemen Pendidikan Nasional.

Rugayah, Retnowati A, Windadri FI \& Hidayat A. 2004. Pengumpulan data taksonomi. Di dalam: Rugayah, Widjaja EA, Praptiwi (eds.). Pedoman Pengumpulan Data Keanekaragaman Flora. Bogor (ID): Puslit-LIPI. hlm 5-42.

Suleiman M, Akiyama H \& Tan BC. 2006. A Revised Catalogue of Mosses Reported from Borneo. J. Hattori Bot. Lab. (99): 107-183.

Suzuki T \& Iwatsuki Z. 2013. Collections of Fissidens (Fissidentaceae, Bryopsida) Made by Messrs. T. Kamiyama and K. Shiina in Laos. Hattoria 4: 47-70.

Suzuki T. 2016. A Revisied New Catalog of the Mosses of Japan. Hattoria 4: 9-233.

Windadri FI. 2010. Keanekaragaman lumut di Taman Nasional Bukit Barisan Selatan, Provinsi Lampung. Berita Biologi 10(2): 159-163. 